\title{
Traditional ecological knowledge of palms by quilombolas communities on the Brazil-Bolivia border, Meridional Amazon
}

\section{Conhecimento ecológico tradicional de palmeiras por comunidades quilombolas na fronteira Brasil-Bolívia, Amazônia Meridional}

Joari Costa de Arruda - Doutorando da Universidade do Estado de Mato Grosso/UNEMAT no Programa de Pós-Graduação em Biodiversidade e Biotcnologia - Rede Bionorte. Mestre em Ciências Ambientais pela UNEMAT. E-mail: arrudajcbio@gmail.com.

Carolina Joana da Silva - Professora da Universidade do Estado de Mato Grosso/UNEMAT, atuando no Programa de Pós-Graduação em Ciências Ambientais. Mestre em Biologia (Ecologia) pelo INPA. Doutora em Ecologia e Recursos Naturais pela UFSCar. E-mail: ecopanta@uol.com.br.

Nilo Leal Sander - Doutorando em Biodiversidade e Biotecnologia - Rede Bionorte. Mestre em Ciências Ambientais pela Universidade do Estado de Mato Grosso - UNEMAT. E-mail: nilosander@gmail.com.

Flávio Bezerra Barros - Professor da Universidade Federal do Pará, atuando nos Programas de PósGraduação em Agriculturas Amazônicas e em Antropologia da UFPA; e Ciências Ambientais da UNEMAT. Mestre em Ciências Biológicas pela Universidade Federal da Paraíba (UFPB) e Doutor em Biologia da Conservação pela Universidade de Lisboa, Portugal. E-mail: flaviobb@ufpa.br.

\section{Resumo}

O trabalho teve como objetivo estudar o conhecimento ecológico tradicional dos quilombolas sobre a diversidade, ocorrência e o uso de palmeiras em Vila Bela da Santíssima Trindade, Mato Grosso. Usamos o método bola de neve, baseado no conhecimento de palmeiras para seleção dos entrevistados e técnica de lista livre. Realizamos 32 entrevistas em três comunidades quilombolas: Boqueirão, Retiro e Casalvasco e Manga. A lista livre mostrou 18 espécies de palmeiras conhecidas, babaçu (Attalea speciosa) foi citada por todos os entrevistados (100\%), açaí (Euterpe precatoria) (94\%), bocaiúva (Acrocomia aculeata) (81\%), acuri (Attalea phalerata), buriti (Mauritia flexuosa L.F.) $(78 \%)$ e tucum (Astrocaryum buaimi) $(75 \%)$. O consenso cultural ficou concentrado em sete espécies nativas. $\mathrm{O}$ conhecimento ecológico tradicional deste grupo social possibilita desenhar um programa participativo de uso sustentável dessas palmeiras em bases ecológicas e culturais.

\section{Palavras-chave}

Uso da biodiversidade. Palmeiras. Comunidades quilombolas. Conhecimento tradicional. Amazônia.

\begin{abstract}
The research had aim to study the traditional ecological knowledge of the quilombolas with regards to diversity, occurrence and use of palms in Vila Bela da Santíssima Trindade, Mato Grosso State. We used the snow ball method, based on knowledge of palms for selection of respondents and free list technique. We conducted 32 interviews in three quilombola communities: Boqueirão, Retiro and Casalvasco and Manga. A free list showed 18 known species of palms. Babassu palm (Attalea speciosa) cited by all interviewees (100\%), Açaí palm (Euterpe precatoria) (94\%), Bocainva (Acrocomia aculeate) (81\%), Acuri (Attalea phalerata) and Buriti (Mauritia flexuosa) (78\%) and Tucum (Astrocaryum buaimi) (75\%). The cultural consensus concentrated on seven native ones. The traditional ecological knowledge of this social group allows for the planning of a sustainable programme of participative usage of these palms on an ecological and cultural basis.
\end{abstract}

\section{Keywords}

Use of biodiversity. Palms. Quilombolas communities. Traditional Knowledge. Amazon. 


\section{INTRODUCTION}

There are 240 genera and 2700 species of Palm recorded worldwide (LORENZI et al., 2010). In its six biomes, Brazil houses 39 genera and 264 species, 107 of which are endemic (LEITMAN et al., 2013). The Amazon and Cerrado biomes contain the greatest number of catalogued species, 147 and 82 respectively. In the state of Mato Grosso there are 41 recorded palm species, placing it sixth behind the states of Amazonas (111), Pará and Acre (76), Bahia (62) and Minas Gerais (54) (LEITMAN et al., 2013).

Some species from the Aracaceae family have ecological and economic potential for the conservation of biodiversity and life strategies of indigenous and traditional peoples in the tropics. (TERBORGH, 1986) reported that palms are considered key species, giving support to ecological interactions of pollination, dispersion and trophic networks of various species. Various authors demonstrate the use of palm from the Attalea, Orbygnia, Euterpe, Syagrus, Acrocomia and Mauritia genera in the in natura nourishment of fruits, starch, sap and heart of palm as well as processed food such as sweets, drinks and oils; in the handicrafts for the production of baskets, bio-jewellery and for the structure and roofing of houses (LÉVI-STRAUSS, 1987; LIMA et al., 2003; GALDINO \& DA SILVA, 2009; GILMORE, 2013).

Although palms have been used for a long time by indigenous peoples, studies that document this interaction (represented by the quilombolas-palms) are emerging. Furthermore, we have found gaps in the occurrence, distribution and records in herbariums of palm species. The shortage of studies draws attention due to the occurrence of various palm species and of peoples, traditional communities and quilombolas in the same territory of the state of Mato Grosso.

In the context of favourable conditions for the development of societynature relations, especially those based in the palm biodiversity and its potential for the sustainability of these social groups, questions around these interactions emerged: Do the quilombolas show Traditional Ecological Knowledge of palm species and their distribution across the landscape? Is the Traditional Ecological Knowledge (TEK) associated to any uses that persist in the community? It was expected that the quilombolas would have a palm TEK related to the diversity of species, their occurrence across the landscape and that they develop handling practices related to them. Thus, this study aimed to investigate: The traditional ecological knowledge of palm diversity in the quilombolas of Vila Bela da Santíssima Trindade; the occurrence of palms in the transition between Cerrado/ Amazonia biomes and; palm usage to aid local and regional development on a sustainable basis.

Novos Cadernos NAEA • v. 17 n. 2 • p. 123-140 • dez. 2014 


\section{THE HUMAN COMMUNITY STUDIED}

The quilombola social category was defined in Brazil (BRASIL, 2003), article 2 as: "racial ethnical groups according to self-attribution criteria, with their own historic trajectory, gifted with specific territorial relations, with presumption of black ancestry related to the resistance against the historical oppression that they suffered". In 2007 (BRASIL, 2007), the Brazilian government instituted the National Policy of Sustainable Development of Peoples and Traditional Communities through legislation number 6.040, including the quilombolas in this category and characterizing them in article 3 as: "Culturally differentiated groups that recognize themselves as such, that possess their own forms of social organization, that occupy and use territories and natural resources as condition for their cultural, social, religious, ancestral and economic reproduction, using knowledge, innovations and practices created and transmitted by tradition".

The quilombolas are descendants of black slaves who survive in community enclaves, often old farms left by the original land owners. Present in Brazil following the abolishment of slavery on the 13th of May 1888, their social emergence is recent, a result of disputes for the lands which generally still do not possess deeds (DIEGUES, 1999). As a consequence of the conflicts with farmers, land invaders and even the State, the quilombolas demand immediate acceptance of their territorial rights, with the demarcation of lands (ALMEIDA, 2006).

The quilombolas that reside in Mato Grosso are descendants of the first slaves who sailed from São Paulo and of those who came to the state between 1752 and 1778, mainly to Vila Bela in order to be sold by the Grão Pará Company (SALLES, 1971; VOLPATO, 1996). Altogether, the majority of slaves that were sent to the state during that period came from central Africa.

In Brazil there are currently 121 issued titles, regulating 988,356,669 hectares benefitting 109 territories, 190 communities and 11,946 quilombola families. There remain 42 decrees of expropriation by social interest and 71 published ordinances recognizing quilombola territories (INCRA, 2013). In the state of Mato Grosso there is only one area with definitive published titles and 64 communities that await demarcation (INCRA, 2013). Claims concerning quilombola lands in the state of Mato Grosso have gained visibility in the last decades, partly favoured by the cultural and historical expression of the population (MACHADO, 2006). Quilombola communities whose TEK was researched in Vila Bela da Santíssima Trindade call themselves Casalvasco and Manga, Retiro and Boqueirão. 


\section{STUDY AREA}

Vila Bela da Santíssima Trindade population is mostly made up of African-descendants, given its phenotypic characteristics that reveal the African origin and also by the cultural elements present in religious events (CARVALHO, 2011), easily observed during the Festança do Glorioso São Benedito, Divino Espírito Santo and the Santíssima Trindade, a religious celebration that takes place annually in the month of July.

The city of Vila Bela da Santíssima Trindade (Figure 1): latitude 1402'00" South and longitude $50^{\circ} 33^{\prime} 40^{\prime \prime}$ "West, covers an area of $13,421.00 \mathrm{~km}^{2}$, with a population of 14,493 inhabitants and a demographic density of 1.08 inhab./ $\mathrm{km}^{2}$. Of these, 5,166 reside in the urban zone and 9,327 in the rural zone, corresponding to $36 \%$ and $64 \%$ of inhabitants respectively (IBGE, 2010).

Figure 1 - Location of the city of Vila Bela da Santíssima'Trindade, Mato Grosso State, Brazil.

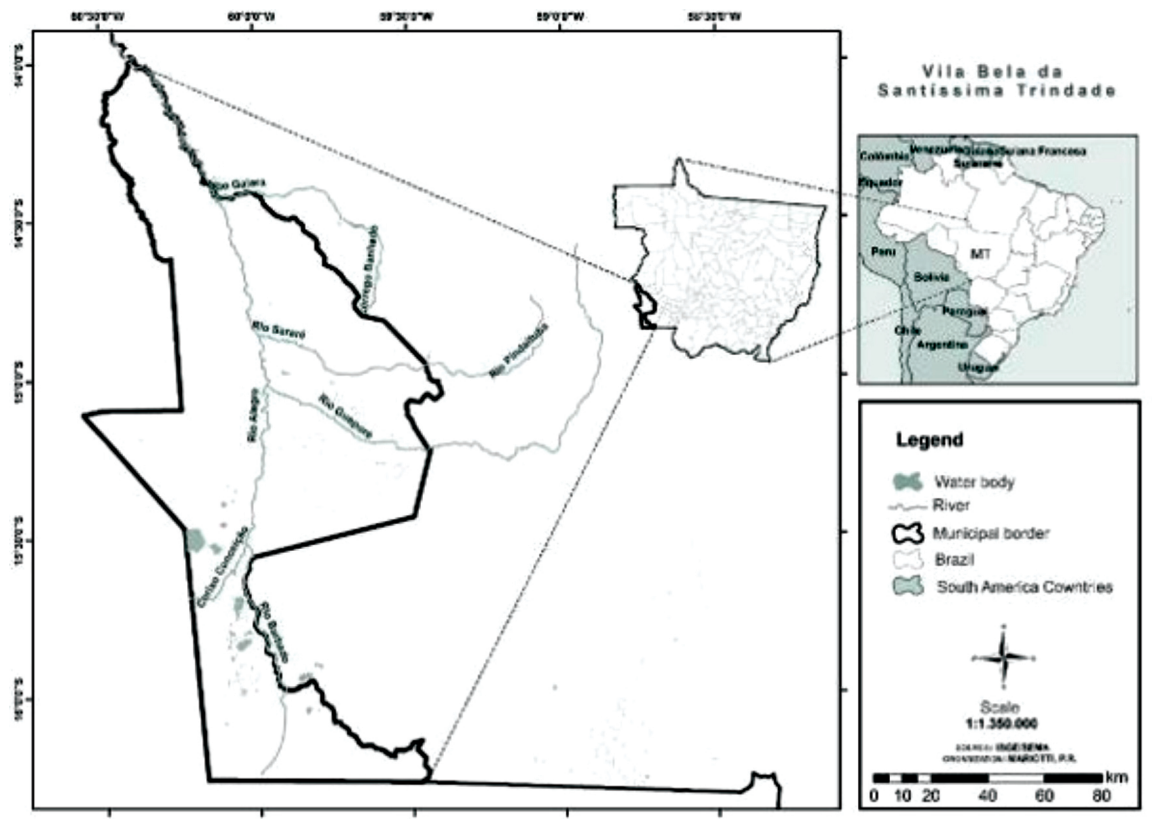

The city's climate is hot tropical and sub-humid with average annual temperatures between $24^{\circ} \mathrm{C}$ and $26^{\circ} \mathrm{C}$ with 4 months of drought. The highest temperatures occur between September to October, reaching $34^{\circ} \mathrm{C}$ with the mildest from June to August (BRASIL, 2008). Annual rainfall amounts to 1,500 $\mathrm{mm}$ with a maximum intensity during December, January and February, reaching more than $3,500 \mathrm{~mm} /$ year in areas of more intense rainfall (ROSS, 2006). 
Vila Bela is situated in the Morphoclimatic Amazonian and Cerrado transition zone (AB' SÁBER, 1967) dominated by four geomorphologic units: Residual Plateaus of Alto Guaporé, Depression of Guaporé, Parecis Plateau, Plains and Wetlands of the Medio and Alto Guaporé, covered by Savanna, Dense Forest, Open Forest and Semi-deciduous Forest (BRASIL, 2007). The city is located on the banks of the Guaporé River, in the sub-basin of the Alto Guaporé, tributary of the Madeira-Mamoré, Amazonian basin.

\section{DATA COLLECTION AND ANALYSIS}

In order to access the traditional ecological knowledge related to palm diversity and occurrence, qualitative and quantitative methods of collection and analysis of typical Ethnobiology and Ethnoecology data were used. Techniques such as structured and semi-structured interviews, participant observation (GEERTZ, 1989; RICHARDSON, 1999) and life history (BERNARD, 2006) were done via forms, records in a field diary and photographic records (VIERTLER, 2002).

Participants were selected using the snowball sampling method (BERNARD, 2006), utilising help from key-informants (ALBUQUERQUE \& LUCENA, 2004). Through the snowball method the participants' indications were noted, illustrated and analysed by using the UCINET 6.403 and NETDRAW 2.120 programs (WELLER \& ROMNEY, 1988).

The indications of recognized palms were done using the Free-List technique, which, through the Anthropac program, facilitated the identification and distinction of the Cultural Domain of the Community. This provided a clear understanding of the definition and limits of what is being studied, according to (BORGAT'TI et al., 2002). The analysis of the free-list, Smith's index of prominence, Cultural Consensus and multidimensional stagger (MDS) were done by using the ANTHROPAC 4 program (BORGAT'TI, 1996; BERNARD, 2006).

The snowball and free list techniques have already been used to study the TEK of the biodiversity of plants used in the construction of traditional housing (GALDINO \& DA SILVA, 2009); of cultivated plants (MORAIS et al., 2009); of plants used in fishing (MORAIS \& DA SILVA, 2010); of birds from the Pantanal (ALMEIDA \& DA SILVA, 2011) and of Pantanal environments (FAÇANHA \& DA SILVA, 2011).

Palm samples known by the participants were collected, exsiccated and added to the Herbarium collection (HPAN). The collection was carried out in 
accordance with the directions and techniques of the (FIBGE, 1992) and the botanical classification in accordance with (APG III, 2009). Cultural practices of use and handling of palms were obtained with the help of structured interviews and participant observation. The research was carried out with the permission of the communities (using consent forms) as well as prior consent from the presidents of the associations linked to the quilombolas.

\section{RESULTS AND DISCUSSION}

Using the snowball method, 32 residents with traditional ecological knowledge of palms were included, from three quilombola communities of Vila Bela da Santíssima Trindade: Boqueirão, Retiro, Casalvasco \& Manga and a key-informant, resident in the urban area. Among those interviewed, 10 were female and 22 male, aged between 37 and 78 with an average age of 56. Due to difficulties in accessing basic education, 18 had no formal schooling, 11 attended or concluded basic education and three finished high school. The palm TEK was transmitted orally and practiced by family members.

HDI data of Vila Bela da Santíssima Trindade (recorded in 2010) was 0.715 and was $88^{\text {th }}$ with regard to state ranking of cities in Mato Grosso and 2,734 $4^{\text {th }}$ position in the national ranking (IBGE, 2010). According to the classification of the Programme of Development for the United Nations (PNUD) (this index puts the city in the category of medium human development (HDI between 0.5 and 0.8 ). Accessing basic education were also a problem in various communities already studied in the state of Mato Grosso (ALMEIDA \& DA SILVA, 2011; FAÇANHA \& DA SILVA, 2011) and Brazil (DIEGUES, 1999; RUFINO et al., 2008), reflecting the regional asymmetry and the social inequality that characterizes Brazil.

The communities we studied showed TEK by identifying 18 palm species, representing 12\% and 16\% of recorded species for the Amazon Forest and Cerrado, according to (LEITMAN et al., 2010). Among the recognized species, the Babassu (Attalea speciosa Mart ex Spreng.) was the most frequently reported (100\%), followed by Açaí palm (Euterpe precatoria Mart.), Bocaiuva (Acrocomia aculeate (Jacq.) Lodd. ex Mart), Acuri (Attalea phalerata Mart. ex Spreng.), Buriti (Mauritia flexuosa L.F.), Tucum (Astrocaryum buaimi Mart.) and Guariroba (Syagrus comosa (Mart.) Mart.) with 94, 81, 78, 78 and 75\% respectively (Table 1).

Smith's index, which integrates frequency and order of citation, identified

Novos Cadernos NAEA • v. 17 n. 2 • p. 123-140 • dez. 2014 
six deviations in the plant knowledge free-list; in the first deviation we see Attalea speciosa (Figure 2a) with an index of (0.940). This palm is among the most important in the cultural domain of the studied communities, being the only specie mentioned by all participants. The second deviation occurred in the Attalea phalerata palm (Figure 2b), index (0.639). This palm was always remembered straight after the Babassu which explains the high index.

The third deviation is among Euterpe precatoria (Figure 2-c), Acrocomia aculeate (Figure 2-d) and Astrocaryum buaimi (Figure 2-e), with indexes 0.512, 0.457 and 0.410 respectively; the fourth deviation occurred between Syagrus comosa (Figure 2-f) and Mauritia flexuosa (Figure 2-g) with respective indexes of 0.359 and 0.336. In these groups the palms display similarity in regards to use and area of occurrence. In these four groups there are species of cultural consensus whose frequency remained above $70 \%$.

Figure 2 - Palms of cultural consensus, first and second deviation: AAttaleaspeciosa; B- Attaleaphalerata. Palmsof natural consensus, thirddeviation:CEuterpe precatoria; D- Acrocomiaaculeata; E- Astrocaryumhuaimi. Palms of natural consensus, fourth deviation: F- Syagruscomosa; G- Mauritiaflexuosa.

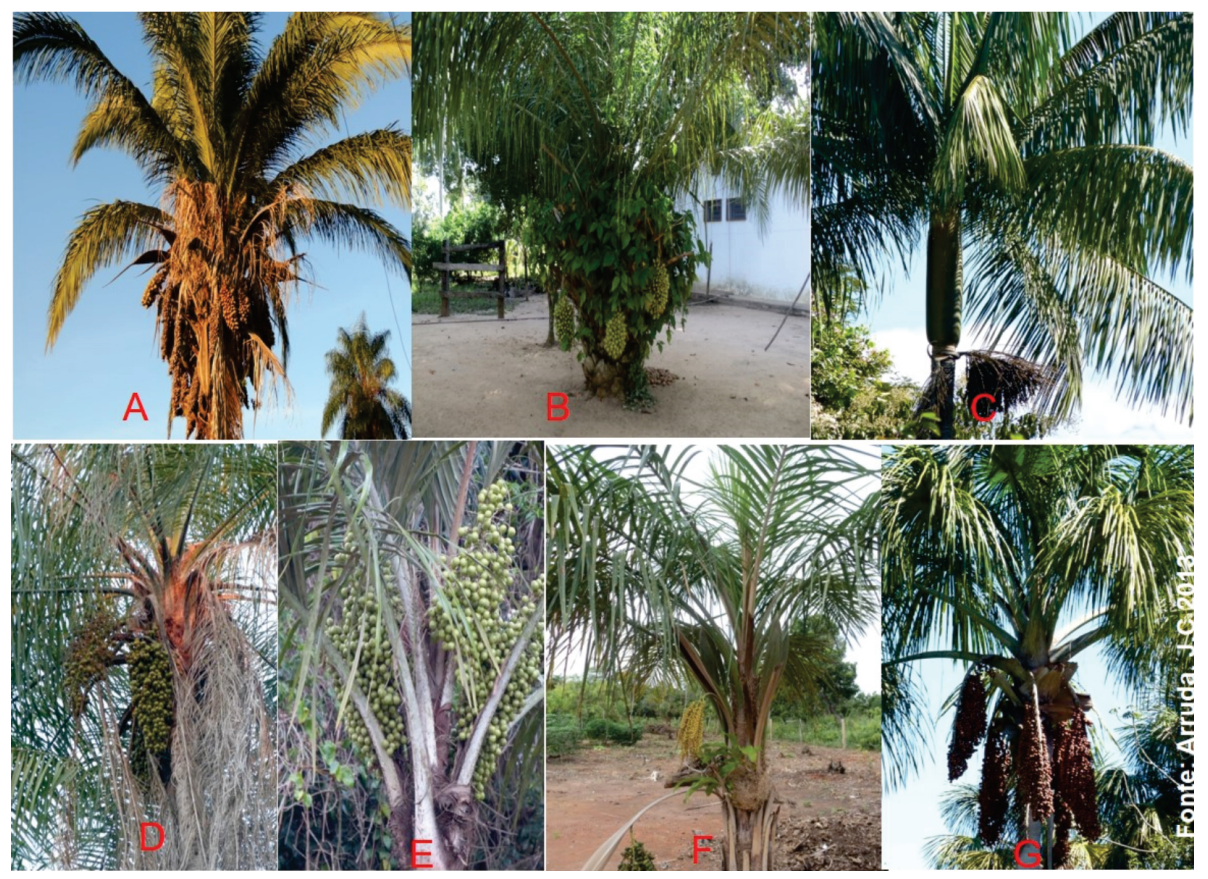

The fifth deviation remained between Mauritiella armata (0.249) and Oenocarpus distichus (0.222); the sixth deviation initiated in the Allagoptera leucocalyx 
palm (0.135) and Attalea maripa (0.006). In this group we found the palm with the lowest frequency of use. Analysis of cultural consensus allows observation of culturally consensual answers through a set of questions and, at the same time, allows the investigator to evaluate the participants' knowledge about a particular cultural domain (BORGAT'TI, 1996).

Table 1 - Traditional ecological knowledge of palm by the Quilombolas of Vila Bela da SantíssimaTrindade, Mato Grosso State and the categories of use: food (A), food for animals (Aa), manure (Ad), handicrafts (Ar), construction (C), fuel $(\mathrm{Cb})$, hygiene $(\mathrm{H})$, medicinal $(\mathrm{M})$, ornamental $(\mathrm{O})$.

\begin{tabular}{|c|c|c|c|c|c|c|c|}
\hline N. & Herbarium & Species & $\begin{array}{c}\text { Ethnospe- } \\
\text { cies }\end{array}$ & $\begin{array}{c}\% \\
n=32\end{array}$ & $\begin{array}{l}\text { Indice de } \\
\text { Smith's }\end{array}$ & $\begin{array}{c}\text { Category of } \\
\text { use }\end{array}$ & $\begin{array}{l}\% \text { of } \\
\text { use }\end{array}$ \\
\hline \multirow[t]{8}{*}{1} & & \multirow{8}{*}{$\begin{array}{l}\text { AttaleaspeciosaMart. } \\
\text { ex Spreng. }\end{array}$} & \multirow[t]{8}{*}{ Babaçu } & \multirow[t]{8}{*}{100} & \multirow[t]{8}{*}{$\underline{0.940}$} & $\mathrm{~A}$ & 100 \\
\hline & & & & & & $\mathrm{Aa}$ & 17 \\
\hline & & & & & & Ad & 3 \\
\hline & & & & & & $\mathrm{Ar}$ & 78 \\
\hline & & & & & & $\mathrm{C}$ & 100 \\
\hline & & & & & & $\mathrm{Cb}$ & 37,5 \\
\hline & & & & & & $\mathrm{H}$ & 17 \\
\hline & & & & & & $\mathrm{M}$ & 6 \\
\hline \multirow[t]{3}{*}{2} & & \multirow{3}{*}{$\begin{array}{l}\text { Attaleaphalerata } \\
\text { Mart. ex Spreng. }\end{array}$} & \multirow[t]{3}{*}{ Acuri } & \multirow[t]{3}{*}{78} & \multirow[t]{3}{*}{$\underline{0.639}$} & $\mathrm{Aa}$ & 2 \\
\hline & & & & & & Ad & 6 \\
\hline & & & & & & C & 19 \\
\hline \multirow[t]{5}{*}{3} & \multirow[t]{5}{*}{$1148 / 1150$} & \multirow{5}{*}{$\begin{array}{l}\text { Euterpe precatori- } \\
\text { aMart. }\end{array}$} & \multirow[t]{5}{*}{ Açaí } & \multirow[t]{5}{*}{94} & \multirow[t]{5}{*}{$\underline{0.512}$} & A & 94 \\
\hline & & & & & & $\mathrm{Aa}$ & 19 \\
\hline & & & & & & $\mathrm{Ar}$ & 9 \\
\hline & & & & & & $\mathrm{C}$ & 22 \\
\hline & & & & & & M & 9 \\
\hline \multirow[t]{2}{*}{4} & \multirow[t]{2}{*}{$1151 / 1152$} & \multirow{2}{*}{$\begin{array}{l}\text { Acrocomiaaculeata } \\
\text { (Jacq.) Lodd. ex } \\
\text { Mart. }\end{array}$} & \multirow[t]{2}{*}{ Bocaiuva } & \multirow[t]{2}{*}{81} & \multirow[t]{2}{*}{0.457} & A & 81 \\
\hline & & & & & & $\mathrm{Aa}$ & 19 \\
\hline \multirow[t]{3}{*}{5} & \multirow[t]{3}{*}{$*$} & \multirow{3}{*}{$\begin{array}{l}\text { Astrocaryumbuaimi } \\
\text { Mart. }\end{array}$} & \multirow[t]{3}{*}{ Tucum } & \multirow[t]{3}{*}{75} & \multirow[t]{3}{*}{0.410} & $\mathrm{~A}$ & 22 \\
\hline & & & & & & $\mathrm{Aa}$ & 9 \\
\hline & & & & & & Ar & 31 \\
\hline \multirow[t]{2}{*}{6} & \multirow{2}{*}{$\begin{array}{l}1136 / 1137 / \\
1144 / 1145\end{array}$} & \multirow{2}{*}{$\begin{array}{l}\text { Syagruscomosa } \\
\text { (Mart.) Mart. }\end{array}$} & Guariroba & 72 & $\underline{0.359}$ & A & 72 \\
\hline & & & & & & $\mathrm{C}$ & 9 \\
\hline 7 & 1154 & Mauritiaflexuosa L.F. & Buriti & 78 & 0.336 & A & 25 \\
\hline & & & & & & $\mathrm{Aa}$ & 9 \\
\hline & & & & & & $\mathrm{Ar}$ & 28 \\
\hline & & & & & & $\mathrm{C}$ & 6 \\
\hline
\end{tabular}




\begin{tabular}{|c|c|c|c|c|c|c|c|}
\hline 8 & $1146 / 1153$ & $\begin{array}{l}\text { Mauritiellaarmata } \\
\text { (Mart.) Burret }\end{array}$ & Carnaíba & 56 & 0.249 & $\mathrm{Ar}$ & 56 \\
\hline 9 & $1138 / 1147$ & $\begin{array}{l}\text { Attaleabarreirensis } \\
\text { Glassman }\end{array}$ & Indaiá & 50 & 0.240 & $\mathrm{C}$ & 50 \\
\hline 10 & 1143 & $\begin{array}{l}\text { Oenocarpusdistichus } \\
\text { Mart. }\end{array}$ & Nortesul & 44 & 0.222 & $\mathrm{O}$ & 44 \\
\hline \multirow[t]{2}{*}{11} & 1133/1134/ & \multirow{2}{*}{$\begin{array}{l}\text { Allagopteraleucocalyx } \\
\text { (Drude) Kuntze }\end{array}$} & \multirow{2}{*}{$\begin{array}{l}\text { Vassour- } \\
\text { inha } \\
\end{array}$} & \multirow[t]{2}{*}{44} & \multirow[t]{2}{*}{$\underline{0.135}$} & $\mathrm{~A}$ & 6 \\
\hline & 1135 & & & & & $\mathrm{Ar}$ & 44 \\
\hline 12 & 1142 & $\begin{array}{l}\text { Bractrisglaucescens } \\
\text { Drude }\end{array}$ & $\begin{array}{l}\text { Tucum- } \\
\text { mirim }\end{array}$ & 25 & 0.110 & A & 25 \\
\hline 13 & 1149 & $\begin{array}{l}\text { Socrateaenxorrbiza } \\
\text { (Mart.) H. Wendl. }\end{array}$ & Setepé & 16 & 0.057 & $\mathrm{Ar}$ & 16 \\
\hline 14 & * & Astrocaryumsp. & Siriva & 22 & 0.042 & $\mathrm{Ar}$ & 22 \\
\hline \multirow[t]{2}{*}{15} & \multirow[t]{2}{*}{ * } & \multirow{2}{*}{$\begin{array}{l}\text { Astrocaryumechina- } \\
\text { tumBarb. Rodr. }\end{array}$} & \multirow[t]{2}{*}{ Tucumã } & \multirow[t]{2}{*}{6} & \multirow[t]{2}{*}{0.040} & $\mathrm{~A}$ & 6 \\
\hline & & & & & & $\mathrm{Ar}$ & 6 \\
\hline 16 & 1141 & $\begin{array}{l}\text { Desmoncuspolyacan- } \\
\text { thos Mart. }\end{array}$ & Urubamba & 9 & 0.015 & $\mathrm{Ar}$ & 9 \\
\hline \multirow[t]{2}{*}{17} & \multirow[t]{2}{*}{ 1139/1140 } & \multirow{2}{*}{$\begin{array}{l}\text { Syagrusvermicularis } \\
\text { Noblick }\end{array}$} & \multirow{2}{*}{$\begin{array}{l}\text { Guariroba } \\
\text { do mato }\end{array}$} & \multirow[t]{2}{*}{3} & \multirow[t]{2}{*}{0.011} & A & 3 \\
\hline & & & & & & $\mathrm{C}$ & 3 \\
\hline 18 & * & $\begin{array}{l}\text { Attaleamaripa } \\
\text { (Aubl.) Mart. }\end{array}$ & Cocalinho & 3 & 0.006 & Semuso & - \\
\hline
\end{tabular}

The Analysis of Consensus indicated that the first factor $(14,240)$ (items from the cultural consensus) was three-fold greater than the second factor $(3,624)$ (further items from the list) (Table 2), suggesting that there was cultural consensus on palm diversity. According to (BORGATTI, 1996), the standard value for the agreement between informants should remain between 0.9 and 1.0. In this study, the value obtained was 0.955 , indicating uniformity among the answers, which can be explained by interviewees having a high level of kinship, origin, phenotypic characteristics, similar socio-economic backgrounds as well as having stayed isolated for decades in the past. This profile was also detected by (MORAIS et al., 2009; MORAIS \& DA SILVA, 2010) in studies related to the cultural consensus in species of plants cultivated and associated with fishing in the community of Estirão Comprido, in the Mato Grosso Pantanal, Brazil. 
Table 2 - Consensus Analysis about the cultural domain of palms in Vale do Guaporé, Mato Grosso State (Pseudo- Reliability = 0,955).

\begin{tabular}{c|c|c|c|c}
\hline Factor & Value & $\%$ variance & $\%$ & Ratio \\
\hline 1 & 14.240 & 69.7 & 69.7 & 3.929 \\
\hline 2 & 3.624 & 17.7 & 87.4 & 1.412 \\
\hline 3 & 2.567 & 12.6 & 100.0 & \\
\hline & 20.432 & 100.0 & & \\
\hline
\end{tabular}

The diagram of Multidimensional Scaling (Figure 3) of the palm knowledge by the quilombolas showed that eleven of the eighteen known species formed a group with the Babassu (A. speciosa) (see image centre), which had obtained 100\% frequency in the interviews and the most elevated Smith's index. This grouping takes into consideration the frequency (how many times the category was indicated) and similarity between the participants' reports in this category. This analysis demonstrates there were similarities in the TEK of these species, by the similarity of Smith's Index or the frequency of the answers, with predominance of the species from the cultural consensus.

Figure 3 - Diagram of Multidimensional Scaling - DMS based on the Jaccard index, grouping of the knowledge of palm species by the participants.

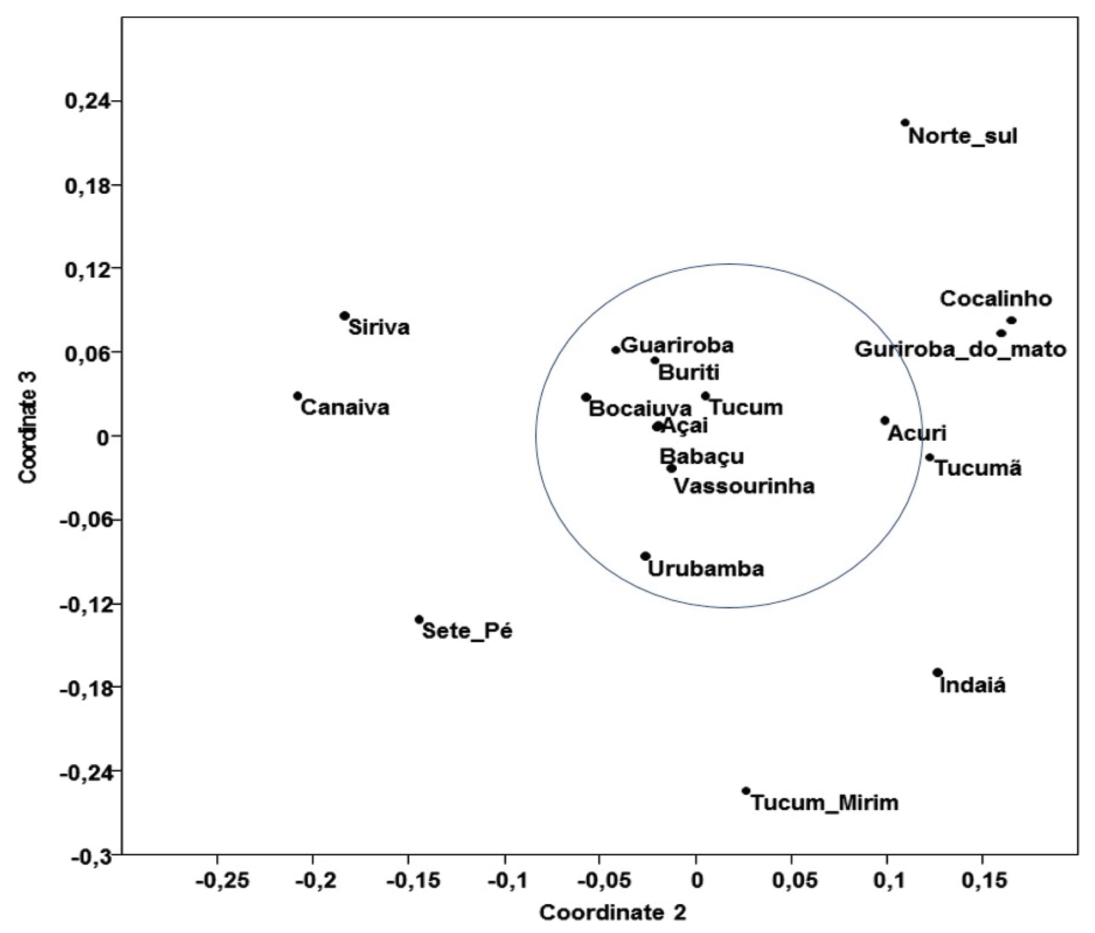

Novos Cadernos NAEA • v. 17 n. 2 • p. 123-140 • dez. 2014 
The palm species of the cultural consensus are those that display the highest Smith's indexes (Table 1); Babassu (A.speciosa), Açaí palm (E. precatoria), Acuri (A. phalerata), Bocaiuva (A. aculeata), Tucum (A. buaimi), Guariroba (S. comosa) and Buriti (M. flexuosa). (GALDINO \& DA SILVA, 2009) observed similar findings, with a cultural consensus in 5 species of "madeiras de chão" (i.e. wood that can be used in direct contact with the ground) such as for out of the 24 species of the cultural domain of plants known in the construction of traditional housing in the community of Cuiabá Mirim, Pantanal of Mato Grosso State.

Regarding the deviations of knowledge, in the first deviation we found only the Babassu specie that stands out among those in cultural domain of the communities. Known palms were included in 9 categories of use by the quilombolas: food (A), food for animals (Aa), manure (Ad), handicraft (Ar), construction $(\mathrm{C})$, fuel $(\mathrm{Cb})$, hygiene $(\mathrm{H})$, medicinal $(\mathrm{M})$, ornamental $(\mathrm{O})$. The 7 species contained in the cultural consensus are those that demonstrated the greatest diversity in terms of use. Of these, the Babassu has known uses in 8 categories with the exception of the ornamental ( $87.5 \%$ of recorded categories). It further explains its dominant position in the Smith ranking (Table 1), being characterised as a specie of multiple uses. This also stands out in other studies (RAMIREZ, 2004; PANIAGUA-ZAMBRANA, 2005; RUFINO et al., 2008; GONZALEZ-PEREZ et al., 2012).

Among the species of the cultural domain (verified from the second deviation), variation occurred with the type and number of use categories in Acuri (A. phalerata), Açaí palm (E.precatoria), Bocaiuva (A. aculeata) and Tucum (A. buaimi). The Acuri is a known source of food for humans, domestic animals, construction, handicraft and manure. (PANIAGUA-ZAMBRANA, 2005) highlights the use of this specie for food, construction, handicrafts and medicine in Bolivia. The Açai is known in the communities for human and animal food, medicinal use, in the construction of housing and handicraft. (CLEMENT et al., 2005) describe the use of the Açaí palm (E. oleracea) for food and of its fruits for cosmetics. In the case of Bocainva there were reports of use as food for humans and domestic animals. Besides these categories of use, (LORENZI \& NEGRELLE, 2006) describe other uses in a study in the Pantanal such as roofing, construction of fences and handicrafts. The Tucum (Astrocaryum buaimi) was mentioned in the use of handicraft and food for humans and pets. (ABREU \& NUNES, 2012) reported that $A$. chambira (from the same genus as the Tucum) is used in construction, handicraft, cosmetics, medicine and food for animals.

As for Guariroba ( $S$. comosa) the uses reported were for food and housing construction while Buriti (M. flexuosa) was used for human and animal food, 
in construction and handicraft. The use of this specie in food, handicraft and construction has also been reported by (SANTOS \& COELHO-FERREIRA, 2012). The species that demonstrated attributes of multiple use are the most susceptible to over-exploitation and even local extinction. Many of them are considered key-species, given the degree of interaction with other species (TERBORGH, 1986; ZONA \& HENDERSON, 1989).

Other factors can contribute (on a larger scale) with the reduction of palm populations due to natural ecosystems being converted for agricultural use. In the State of Mato Grosso, the transition region between the Cerrado and Amazonia biomes has the highest conversion rates. According to (HAYASHI et al., 2011), the most recent deforestation rates indicate that the state of Mato Grosso leads the ranking of deforestation with $77 \%$. In absolute terms it represents an area of 994 square kilometers of accumulated deforestation.

The majority of the timber is covertly removed for use in wood working industry and coal furnaces. Added to these are mining activities which together cause soil erosion and degradation of various types of vegetation, possibly leading to an extinction of species which could have been used by the local communities (BRANDON et al., 2005).

In the Cerrado, the modifications are overtly visible as, in recent years, large natural areas were converted to pastures for livestock which would be expanded through wild-fires (TABARELLI \& GASCON, 2005; KLINK \& MACHADO, 2005). The monoculture of genres such as corn, soya and cotton, cultivated on a large scale, modifies the landscape through the conversion of ecosystems. Only the 2012/2013 harvest (IBGE, 2010) represents conversion of $17,658,376$ hectares for pasture, 6,980,690 and 2,740,833 million respectively for soya and corn plantations.

The conversion of these biomes by the activities of agriculture and livestock can lead to the extinction of palm species, bringing about the loss of biological and cultural diversity, reducing food safety and eliminating alternatives of sustainable use by other social groups such as the quilombolas (who depend on these resources for their ecological and cultural reproduction). Thus, it's important to highlight that the Amazonian biome possesses nearly 30\% of all existing species, which includes more than 30 thousand species of superior plants, including palm trees (IBGE, 2010).

In the study area, the Babassu (Attalea speciosa Mart. Ex Spreng.) and Açaí palm (Euterpe precatoria Mart) are the species with a greater diversity of use and are also the most over-exploited. It has been reported that the Açaí palm population has been diminished in certain areas whilst in others they are locally 
extinct in function of the extraction of heart of palms, without management and the opening of new areas for pasture. "In the past, Açaí palm could be found everywhere around here, on the banks of the Alegre river there were a lot. Now, it's found in few places. What killed off the Açaí were the pastures and the palmiteiros who knocked them down to sell heart of palms" (participant 10, male, 78 years old, resident of Casalvasco and Manga).

These conditions raise the risk of the decline of the palm population due to the fact that livestock practices dominate the city of Vila Bela (having the $2^{\text {nd }}$ most cattle in the state and the $5^{\text {th }}$ in the country; with a herd of 888,430 cattle) and is also the $10^{\text {th }}$ largest milk producer in the (IBGE, 2010).

\section{FINAL CONSIDERATIONS}

The quilombolas of Boqueirão, Retiro and Casalvasco \& Manga in Vila Bela da Santíssima Trindade retain a wide traditional ecological knowledge as shown by the list of palm species known to the communities. The traditional ecological knowledge recorded 18 palm species whose cultural consensus remained focused on seven native species: A. speciosa, E. precatoria, A. phalerata, A. aculeate, A. huaimi, S. comosa and M. flexuosa. The Babassu (A. speciosa) is among the most important in the cultural domain of the studied communities being the only specie mentioned by all the participants interviewed. This knowledge can contribute towards strengthening environmental public policies that aim to: 1) Conserve areas of native vegetation; 2) recover degraded areas; 3 ) Enrich habitats; 4) Promote improvement in the quality of the environment; 5) guarantee the operation of the ecosystem and the strengthening of the local cultural identity.

\section{ACKNOWLEDGEMENTS}

To the Retiro, Boqueirão and Casalvasco and Manga quilombola communities for their support and for sharing their palm knowledge; to the financial and scientific support from Rede Bionorte "Projeto conservação, use and bio-prospection of biodeversity of Meridional Amazon-Mato Grosso" under the auspices of MCTI/CNPq/FAPEMAT; to the University of the State of Mato Grosso (UNEMAT), for the opportunity of qualification and masters scholarship conceded; to the Coordenação de Aperfeiçoamento de Pessoal de Nível Superior (Capes). 


\section{REFERENCES}

AB'SÁBER, A. N. Domínios Morfoclimáticos e províncias fitogeográficas do Brasil. Orientação, n. 3, 1967.

ABREU, R.; NUNES, N. L. Tecendo a tradição e valorizando o conhecimento tradicional na Amazônia: o caso da "linha do tucum". Horizontes Antropológicos, Porto Alegre, ano 18, n. 38, p. 15-43, jul./dez, 2012.

ALBUQUERQUE, U. P. de; LUCENA, R. F. de P. Métodos e Técnicas na Pesquisa Etnobotânica. Recife: Livrorápido; NUPEEA, 2004.

ALMEIDA, A. W. B. de Palafitas do Jenipapo na ilha de Marajó: a construção da terra, o uso comum das águas e o conflito. Novos Cadernos NAEA, Belém, v. 9, n. 1, p. 25-76, jun. 2006.

ALMEIDA, A. W. B. Conhecimentos tradicionais "Uma nova agenda de temas e problemas conflitos entre o poder das normas e a força das mobilizações pelos direitos territoriais". Caderno de Debates Nova Cartografia Social, v. 1, n. 1, 2010.

ALMEIDA, M. A.; DA SILVA, C. J.. As comunidades tradicionais pantaneiras Barra de São Lourenço e Amolar, Pantanal, Brasil. História e Biodiversidade. v. 1, n 1. 2011.

APG III. An update of the Angiosperm Phylogeny Group classification for the orders and families of flowering plants: APG III. Botanical Journal of the Linnean Society. v. 161 , p. $105-121,2009$.

BERNARD, H. R.. Research Methods in Anthropology: Qualitative and Social Mechanisms for Build Quantitative Approaches. New York: Altamira Press, 2006. $803 \mathrm{p}$.

BORGATTI, S. P. ANTHROPAC 4.0 Methods Guide. Natick: Analytic Technologies, 1996.

BORGATTI, S. P.; EVERETT, M. G; FREEMAN, L. C. Ucinet for Windows: Software for Social Network Analysis. Harvard: Analytic Technologies. 2002. Disponível em: $<$ http://www.analytictech.com/ucinet/download.htm>. Acesso em: 10 may 2012.

BRANDON, K.; FONSECA, G. A. B.; RYLANDS, A. B. SILVA, J. M. C. da. Conservação brasileira: desafios e oportunidades. Megadiversidade, v. 1, n. 1, p. 7-13, 2005.

BRASIL. Decreto $\mathbf{N}^{\mathbf{0}} \mathbf{4 . 8 8 7}$, de 20/11/2003. Regulamenta o procedimento para identificação, reconhecimento, delimitação, demarcação e titulação das terras ocupadas por remanescentes das comunidades dos quilombos. 2003.

BRASIL. Decreto $\mathbf{N}^{\mathbf{0}} \mathbf{6 . 0 4 0}$, de 7/02/2007. Institui a Política Nacional de Desenvolvimento Sustentável dos Povos e Comunidades Tradicionais. 2007. 
BRASIL. Plano Amazônia Sustentável: diretrizes para o desenvolvimento sustentável da Amazônia Brasileira / Presidência da República. Brasília: MMA, 2008.

BRASIL. Projeto Brasil das águas, Sete Rios. Brasília, 2007.

CARVALHO; P. M. de. Vila Bela e seus quilombos: etnoarqueologia aplicada aos estudos da diáspora africana: In: SIMPÓSIO NACIONAL DE HISTÓRIA, 26. 2011. São Paulo. Anais... São Paulo: ANPUH, 2011.

CLEMENT, C. R.; LLERAS P, E; VAN LEEUWEN, J. O potencial das palmeiras tropicais no Brasil: acertos e fracassos das últimas décadas. Agrociencia, v. 9, n. 1-2, p. $67-71,2005$.

DIEGUES, A. C. (Org.). Biodiversidade e Comunidades Tradicionais no Brasil. São Paulo: NUPAUB/USP; POBIO/MMA-CNPq, 1999.

FAÇANHA, C. L.; DA SILVA, C. J. Comunidade Pantaneira Barra de São Lourenço: Modo de vida e rede social. In: SANTOS, J. E.; GALBIATI, C; MOSCHINI, L. E. (Orgs): Gestão e educação ambiental: água, biodiversidade e cultura. v. 4. São Carlos: RiMa, 2011.

GALDINO, Y. S. N.; DA SILVA, C. J. Casa e Paisagem pantaneira: conhecimento e práticas tradicionais. Cuiabá: Carlini\&Cniato, 2009.

GEERTZ, C. A Interpretação das Culturas. Rio de Janeiro: Zahar, 1989.

GILMORE, M. P.; ENDRESS, B. A.; HORN, C. M. The socio-cultural importance of Mauritia flexuosa palm swamps (aguajales) and implications for multi-use management in two Maijuna communities of the Peruvian Amazon. Journal of Ethnobiology and Ethnomedicine, 2013.

GONZALEZ-PEREZ, S. E.; COELHO-FERREIRA, M.; ROBERT, PA.; LOPEZ GARCES, C. L. Conhecimento e usos do Babassu (Attalea speciosa Mart. e Attalea eichleri (Drude) A. J. Hend.) entre os Mebêngôkre-Kayapó da Terra Indígena Las Casas, estado do Pará, Brasil. Acta Botanica Brasilica, v. 26., n. 2, p. 295-308. 2012.

HAYASHI, S.; SOUZA JR., C.; SALES, M.; VERISSIMO, A.. Boletim Transparência Florestal Amazônia Legal. Belém: Imazon. 2011. p. 17.

IBGE- Instituto Brasileiro de Geografia e Estatística. Anuário Estatístico do Brasil, 1992. Rio de Janeiro: FIBGE, 1992.

IBGE. Instituto Brasileiro de Geografia e Estatística. Anuário Estatístico do Brasil, 2010. Rio de Janeiro: FIBGE, 2010.

INCRA-Instituto Nacional de Colonização e Reforma Agrária, 2013. Disponível em $<$ http://www.incra.gov.br/index.php/estrutura-fundiaria/quilombolas $>$ acesso em: 12 mar. 2013.

KLINK, C. A.; MACHADO, R. B. A conservação do Cerrado brasileiro. Megadiversidade, v. 1, n. 1, p. 147-155, 2005. 
LEITMAN, P.; HENDERSON, A.; NOBLICK, L.. Arecaceae. In: Lista de Espécies da Flora do Brasil. Rio de Janeiro: Jardim Botânico do Rio de Janeiro, 2013. Disponível em <http://floradobrasil.jbrj.gov.br/2010/FB000053>. Acesso em: 19 mar. 2013.

LÉVI-STRAUSS, C. O uso das plantas silvestres da América do Sul tropical. In:RIBEIRO, Berta G. (Cord). SUMA Etnológica Brasileira: Etnobiologia. 2. ed. Petrópolis: Vozes, 1987.

LIMA, E. S.; FELFILI, J. M.; MARIMON, B. S.; SCARIOT, A.. Diversidade, estrutura e distribuição espacial de palmeiras em um Cerrado sensu stricto no Brasil Central-DF. Revista Brasil. Bot., v. 26, n. 3, p.361-370, jul.-set. 2003.

LORENZI, G. M. A. C.; NEGRELLE, R.. R. B. Acrocomia aculeata (Jacq.) Lodd. ex Mart.: aspectos ecológicos, usos e potencialidades. Visão Acadêmica, Curitiba, v. 7, 2006.

LORENZI,H.;NOBLICK, L.; KAHN, F.; FERREIRA, E... Flora Brasileira:Arecaceae (palmeiras). Nova Odessa: Instituto Plantarum, 2010.

MACHADO, M. F. R. Quilombos, Cabixis e Caburés: índios e negros em Mato Grosso no século XVIII. Reunião Brasileira de Antropologia 25, 2006. Goiânia. Anais... Goiânia: ABA, 2006. MORAIS F. F.; DA SILVA, C. J. Conhecimento ecológico tradicional sobre fruteiras para pesca na Comunidade de Estirão Comprido, Barão de Melgaço - Pantanal Matogrossense. Biota Neotropica, v. 10, n. 3. 2010.

MORAIS, F. F.; MORAIS; R. F.; DA SILVA, C. J. Conhecimento ecológico tradicional sobre plantas cultivadas pelos pescadores da comunidade Estirão Comprido, Pantanal Matogrossense, Brasil. Boletim do Museu Paraense Emílio Goeldi-Ciências Humanas, Belém, v. 4, n. 2, p. 277-294, maio-ago. 2009.

OLIVEIRA, M. C. C, ALMEIDA, J. SILVA, L. M. S. - Diversificação dos sistemas produtivos familiares: reflexos sobre as relações sociedade-natureza na Amazônia Oriental. Belém, Novos Cadernos Naea, v. 14, n. 2, p. 61-88, dez. 2011.

PANIAGUA-ZAMBRANA, N. Y. Diversidad, densidad, distribución y uso de las palmas en la región del Madidi, noreste del departamento de La Paz (Bolivia). Ecología en Bolivia, v. 40, n.3, p. 265-280, Dic. 2005.

RAMÍREZ, M. M. Flora de palmeras de Bolivia. La Paz: Herbario Nacional de Bolivia; Instituto de Ecología; Carrera de Biologia; Universidad Mayor de San Andrés, 2004.

RICHARDSON R. J. Pesquisa Social: métodos e técnicas. 3.ed. São Paulo: Atlas: 1999. $334 \mathrm{p}$.

ROSS, J. L. S. Ecogeografia do Brasil: subsídios para Planejamento Ambiental. São Paulo: Oficina de Textos, 2006. 
RUFINO, M. U; COSTA, J. T. de M; SILVA, V. A; ANDRADE, L. de H. C. Conhecimento e uso do ouricuri (Syagrus coronata) e do Babassu (Orbignya phalerata) em Buíque, PE, Brasil. Acta Botanica Brasilica, v. 22, n. 4, p. 1141-1149, 2008.

SALleS, V. O negro no Pará. Belém: Universidade Federal do Pará; Fundação Getúlio Vargas, 1971.

SANTOS, R. da S.; COELHO-FERREIRA, M. Estudo etnobotânico de Mauritia flexuosa L. f. (Arecaceae) em comunidades ribeirinhas do Município de Abaetetuba, Pará, Brasil. Acta Amazonica, v. 42, n. 1, p. 1-10, 2012.

TABARELLI, M; GASCON, C.. Lições da pesquisa sobre fragmentação: aperfeiçoando políticas e diretrizes de manejo para a conservação da biodiversidade. Megadiversidade, v. 1, n. 1, jul. 2005.

TERBORGH, J. Keystone plants resources in the tropical forest. Conservation Biology, Massachussetts: Sinauer, 1986. p. 330-344.

VIERTLER, R. B. Métodos antropológicos como ferramenta para estudos em etnobiologia e etnoecologia. In: AMOROZO, M. C. M.; MING, L. C.; SILVA, S. M. P. (Eds.). Métodos de coleta e análise de dados em etnobiologia, etnoecologia e disciplinas correlatas. Rio Claro: UNESP/CNPq, 2002.

VOLPATO, L. R. R. Quilombos em Mato Grosso: resistência negra em área de fronteira. In: REIS, J. J; GOMES, F. dos S.. (orgs.). Liberdade por um fio: história dos quilombos no Brasil. São Paulo: Companhia das Letras, 1996.

WELLER, S. C.; ROMNEY, A. K. (Ed.). Systematic data collection. Sage, 1988.

ZONA, S.; HENDERSON, A.. A review of animal-mediated seed dispersal of palms. Selbyana, p. 6-21, 1989. 
